\title{
In vitro cytotoxic properties of Ipomoea aquatica leaf
}

Efforts are being made to develop anticancer agents from natural sources by many workers. In the past, plants have provided anticancer compounds like vincristine and taxol. Several members of the species Ipomoea (Convolvulaceae) are being used traditionally for the treatment of a large number of disease conditions. Among them Ipomoea bahiensis is reported to posses anticancer activity. ${ }^{[1]}$ Ipomoea aquatica leaf is being used as a green leafy vegetable and also in traditional medicine for nose bleed and high blood pressure with high antioxidant properties. ${ }^{[2]}$ No investigation has been carried out for its anticancer property till now. In view of these reports and ethnomedical uses of Ipomoea aquatica leaf, we studied the in vitro cytotoxic properties of its crude methanolic extract (CME), its column fraction (CF) and purified bioactive compound i.e., 7-O- $\beta$-D-glucopyranosyl-dihydroquercetin-3-O- $\alpha$-Dglucopyranoside (DHQG) isolated from it.

The leaves of Ipomoea aquatica were collected from Mysore, Karnataka, India, authenticated by a taxonomist and a specimen preserved (specimen no: 9/1) at the Department of Botany, University of Mysore, Mysore. The leaves (628 g) were oven dried at $48^{\circ} \mathrm{C}$ for $36 \mathrm{~h}$ to prevent enzyme action, ${ }^{[3]}$ powdered and extracted with methanol $(2.5 \mathrm{l})$ in a Soxhlet extractor for $8 \mathrm{~h}$. The extract was concentrated under reduced pressure and controlled temperature to yield CME (146 g, $23.3 \%)$. This extract ( $60 \mathrm{~g}$ ) was purified partially by using silica column chromatography to obtain the CF. This fraction was in turn purified by using XAD-4 resin column chromatography to obtain a pure compound $(1.7 \mathrm{~g})$. This $100 \%$ pure compound based on UV, NMR and GC-MS studies was identified as DHQG. ${ }^{[2]}$ Each test sample (CME, CF and DHQG) were separately dissolved in 1\% dimethyl sulphoxide ${ }^{[4]}$ (DMSO) and the volume was made up to $10 \mathrm{ml}$ with Dulbecco's modified Eagles medium (DMEM), pH 7.4 supplemented with 2\% heat inactivated newborn calf serum (Maintenance medium, PAA Laboratories, Austria), to obtain a stock solution of $1 \mathrm{mg} / \mathrm{ml}$ concentration, sterilized by filtration and stored at $-20^{\circ} \mathrm{C}$ till use.

The CME, CF and DHQG were investigated for cytotoxic properties against normal and cancer cell lines. Vero (normal African green monkey kidney) and Hep-2 (human larynx epithelial carcinoma) cell lines were obtained from Pasteur Institute of India, Coonor. A-549 (human small cell lung carcinoma) was obtained from National Center for Cell Sciences, Pune. The cultures were maintained in DMEM, $\mathrm{pH}$ 7.4 supplemented with $10 \%$ heat inactivated newborn calf serum, ${ }^{[5]}$ penicillin $(100 \mathrm{IU} / \mathrm{ml})$, streptomycin $(100 \mu \mathrm{g} / \mathrm{ml})$ and amphoterecin-B $(5 \mu \mathrm{g} / \mathrm{ml})$ and were grown in $25 \mathrm{~cm}^{2}$ tissue culture flasks (Tarsons Products [P] Ltd., Kolkata, India) until confluent and used for cytotoxicity assays.

Cell lines in exponential phase were washed with serum free DMEM medium, trypsinised using $0.2 \%$ trypsin and re- suspended in DMEM medium with 10\% heat inactivated newborn calf serum. ${ }^{|5|}$ Cells were plated at 10,000 cells/well in 96 well microtiter plates (Tarsons Products [P] Ltd., Kolkata, India) and incubated for $24 \mathrm{~h}$ at $37^{\circ} \mathrm{C}, 5 \% \mathrm{CO}_{2}$ in a humidified atmosphere, during which period a partial monolayer was formed. The cells were then exposed to different concentrations (15.6, 31.2, 62.5, 125, 250, 500 and $1000 \mathrm{mg} / \mathrm{ml}$, prepared by serial two-fold dilutions using maintenance medium from the stock solution) of test sample in quadruplicate. Control wells received only maintenance media. The cells were incubated at $37^{\circ} \mathrm{C}$ in a humidified incubator with $5 \% \mathrm{CO}_{2}$ for a period of $72 \mathrm{~h}$ according to method of Brown ${ }^{[4]}$ et al., (2004). Morphological changes were examined using an inverted tissue phase-contrast microscope (Olympus Optical Co., Ltd., Japan, Model 1X70) at $24 \mathrm{~h}$ time intervals and compared with the control. At the end of $72 \mathrm{~h}$, cellular viability was determined using standard 3-(4,5-Dimethylthiazol-2-yl)-2,5-diphenyl tetrazolium bromide (MTT) ${ }^{[6]}$ and Sulphorhodamine B (SRB) ${ }^{[7]}$ assays and the $\mathrm{CTC}_{50}$ value (concentration of the sample required to kill $50 \%$ of the cells) was calculated.

DHQG showed cytotoxicity towards cell cultures with CTC $_{50}$ values of $387 \mathrm{mg} / \mathrm{ml}$ against normal Vero cell line, where as 156 and $394 \mathrm{mg} / \mathrm{ml}$, against Hep-2 and A-549 cell lines respectively. The $\mathrm{CME}$ and $\mathrm{CF}$ gave $\mathrm{CTC}_{50}$ values ranging from 41-332 mg/ml in Vero, $46-114 \mathrm{mg} / \mathrm{ml}$ in Hep-2 and $44-230$ $\mathrm{mg} / \mathrm{ml}$ in A-549 cell lines. [Table 1]

The CME was more potent than that of DHQG probably due to synergistic effects resulting from the combination of anthocyanins and other phenolic compounds. ${ }^{[8 \mid}$ Presence of

\section{Table 1}

Cytotoxic activity of Ipomoea aquatica on different cell lines by MTT and SRB assays

\begin{tabular}{lcccc}
\hline \multirow{2}{*}{ Test samples } & Cell line & \multicolumn{3}{c}{${ }^{*} \boldsymbol{C T C}_{50}(\mathbf{m g} / \mathbf{m})^{a}$} \\
\cline { 3 - 5 } CME & Vero & $44.3 \pm 4$ & SRB & Mean \\
& Hep-2 & $43 \pm 4.3$ & $49 \pm 1.4$ & $41 \pm 2.7$ \\
& A-549 & $47 \pm 5$ & $41.3 \pm 0$ & $46 \pm 3.5$ \\
CF & Vero & $326.3 \pm 9.1$ & $338 \pm 12.7$ & $332 \pm 10.9$ \\
& Hep-2 & $116.6 \pm 4.9$ & $112.3 \pm 4.9$ & $114 \pm 4.9$ \\
& A-549 & $232.6 \pm 7$ & $228 \pm 7$ & $230 \pm 7$ \\
DHQG & Vero & $390.6 \pm 5$ & $385 \pm 2.8$ & $387 \pm 3.9$ \\
& Hep-2 & $156.6 \pm 1.6$ & $155.3 \pm 0$ & $156 \pm 0.8$ \\
& A-549 & $393.6 \pm 7.7$ & $395.3 \pm 3.5$ & $394 \pm 5.6$
\end{tabular}

average of three independent determinations, 4 replicates, values are mean $\pm \mathrm{SEM},{ }^{*} \mathrm{CTC}_{50}=$ Concentration of the sample required to kill $50 \%$ of the cells. $\mathrm{CME}=$ Crude methanolic extract, $\mathrm{CF}=$ Column fraction, $\mathrm{DHQG}=7-\mathrm{O}-\mathrm{B}-$ D-glucopyranosyl-dihydroquercetin-3-O- $\alpha$-D-glucopyranoside. MTT assay $=3$ (4,5-Dimethylthiazol-2-yl)-2,5-diphenyl tetrazolium bromide, SRB assay = Sulphorhodamine B. 
sugar moiety in DHQG may be attributed to its low activity, probably due to steric hindrance by addition of sugar moieties. ${ }^{[9]}$ The results of $\mathrm{CTC}_{50}$ values thus obtained indicate that DHQG showed cytotoxicity towards cancer cell lines tested. Hence further investigations are required to prove the toxicity of DHQG in vivo.

\section{K.N. Prasada, G. Ashokb, C. Raghub, G.R. Shivamurthya, P. Vijayan', S.M. Aradhyac}

aDepartment of Studies in Botany, Manasagangotri, Mysore-6, bJS College of Pharmacy, Rocklands, Ootacamund-643001 and 'Department of Fruit and Vegetable Technology,

CFRTI, Mysore-570020.

E-mail: aradhyasm@yahoo.co.in

\section{References}

1. Bieber LW, Filho AADS, Rosalia MO, Lima C, Chiappeta AD, Nascimento SC, et al. Anticancer and antimicrobial glycosides from Ipomoea bahiensis. Phytochemistry 1986;25:1077-81.

2. Prasad KN, Divakar S, Shivamurthy GR, Aradhya SM. Isolation of a free radical-scavenging antioxidant from water spinach (Ipomoea aqutica Forsk.). J Sci Food Agric. In press 2005.

3. Markham KR. Techniques of flavonoid identification. London: Academic Press; 1982.

4. Brown R, Boger-Brown U. Methods in Molecular Medicine. Vol 28: Cytotoxic Drug Resistance Mechanism.Totowa, NJ: Humana Press; 1999.

5. Freshney RI, Culture of animal cells-A manual of basic technique. New York: John Wiley \& Sons, Inc Publications; 2000.

6. Francis D, Rita L. Rapid colorometric assay for cell growth and survival modifications to the tetrazolium dye procedure giving improved sensitivity and reliability. J Immunol Methods 1986;89:271-7.

7. Skehan P, Storeng R, Scudiero D, Monks A, McMahon J, Vistica D, et al. New colorimetric cytotoxic assay for anti-cancer drug screening. J Natl Cancer Inst 1990;82:1107-12.

8. Seeram NP, Adams LS, Hardy ML, Heber D. Total cranberry extract versus its phytochemical constituents: Antiproliferative and synergestic effects against human tumor cell lines. J Agric Food Chem 2004;52:2512-7.

9. Koide T, Hashimoto Y, Kamei H, Kojima T, Hasgawa M, Terabe K. Antitumor effect of anthocyanin fractions extracted from red soybeans and red beans in vitro and in vivo. Cancer Biother Radiopharm 1997;12:277-80.

\section{Annual Conference of the Indian Pharmacological Society}

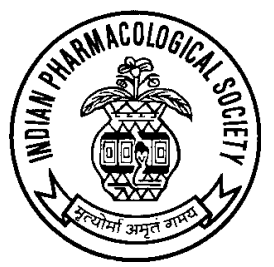

\section{December 28 - 30, 2005 IMAGE Auditorium, Chennai}

For further information please contact:

Dr. C. B. Tharani

Institute of Pharmacology,

Madras Medical College, Chennai.

E-mail: ips_38con@yahoo.co.in

Website: ips38chennai.com 